\title{
Efektivitas Terapi Kelompok Pendukung terhadap Kesejahteraan Subjektif pada Pasien HIV/AIDS
}

\author{
Tia Prasyatiani ${ }^{1}$ \\ Rr. Indahria Sulistyarini \\ Program Studi Psikologi Profesi (S2) Universitas Islam Indonesia, Yogyakarta
}

\begin{abstract}
This study aimed to determine the effect of support group therapy on subjective wellbeing in patients living with HIV / AIDS. Therapy with pretest-post-test design of the control and experimental groups was carried out in 3 meetings for approximately 1 week. Subjects in this study are patients living with HIV / AIDS. The experimental group $(n=3)$ is the group that received intervention in the form of support group therapy, while the control group $(n=3)$ as the waiting list group. This study used 2 scales to measure subjective well-being, which are Satisfaction With Life Scale (SWLS) to measure cognitive aspects and Positive And Negative Affect Scale (PANAS) to measure the affective aspects. The results of the study showed that support group therapy could increase the subjective well-being of patients living with HIV / AIDS.
\end{abstract}

Keyword: support group therapy, patients living with HIV, subjective well-being

ABSTRAK: Penelitian ini bertujuan untuk mengetahui pengaruh terapi kelompok pendukung terhadap kesejahteraan subjektif pada pasien HIV/AIDS. Terapi yang menggunakan desain pretes-pascates kelompok kontrol dan eksperimen ini dilaksanakan dalam 3 kali pertemuan selama kurang lebih 1 minggu. Subjek penelitian merupakan pasien dengan HIV/AIDS. Kelompok eksperimen $(\mathrm{n}=3)$ adalah kelompok yang menerima intervensi berupa terapi kelompok pendukung, sedangkan kelompok kontrol $(\mathrm{n}=3)$ sebagai kelompok waiting list. Penelitian ini menggunakan 2 buah skala untuk mengukur kesejahteraan subjektif, di antaranya adalah Satisfaction With Life Scale (SWLS) untuk mengukur aspek kognitif dan Positive And Negative Affect Scale (PANAS) untuk mengukur aspek afeksi. Hasil penelitian menunjukkan bahwa terapi kelompok pendukung dapat meningkatkan kesejahteraan subjektif pasien HIV/AIDS.

Kata kunci: terapi kelompok pendukung, pasien HIV, kesejahteraan subjektif

${ }^{1}$ Korespondensi mengenai artikel ini dapat melalui tprasyatiani@gmail.com 
Kesejahteraan subjektif adalah penilaian pribadi individu tentang hidupnya, bukan berdasarkan penilaian dari ahli, termasuk di dalamnya mengenai kepuasan (baik secara umum, maupun pada aspek spesifik), afek yang menyenangkan dan rendahnya tingkat afek yang tidak menyenangkan (Diener, Scollon, Lucas, 2003). Rendahnya afek menyenangkan menunjukkan rendahnya kesejahteraan subjektif individu. Individu dengan kesejahteraan subjektif rendah menilai keadaan hidup dan peristiwa yang terjadi sebagai hal tidak diinginkan, dan karenanya merasakan emosi yang tidak menyenangkan seperti kecemasan, depresi, dan kemarahan (Aprilia, 2015). Rendahnya afek menyenangkan dan aspek kognitif sering kali dikaitkan dengan keadaan fisik yang tidak sempurna. Keadaan ini seringkali terjadi pada individu yang secara fisik mengalami kemunduran energi, misalnya pada pasien penyakit kronis, termasuk di dalamnya HIV/AIDS. Senada dengan pernyataan tersebut, Simon (2011) mengatakan penyakit kronis secara konsisten berkaitan erat dengan meningkatnya emosi yang tidak menyenangkan seperti gangguan depresi dan juga kerapkali membuat shock.

Human Immunodeficiency Virus (HIV) menyerang sistem kekebalan tubuh, khususnya sel CD4 (sel T), yang berfungsi melawan infeksi. Seiring berjalannya waktu, HIV dapat menghancurkan begitu banyak sel sehingga tubuh tidak dapat melawan infeksi dan penyakit. Infeksi ini kemudian mempengaruhi sistem kekebalan tubuh yang sangat lemah dan dapat menjadi tanda bahwa individu positif AIDS sebagai dampak terakhir dari infeksi HIV.

Berdasarkan data yang diperoleh dari World Health Organization - HIV Department, pada tahun 2015 terdapat lebih kurang 2,1 juta individu baru yang terjangkit HIV di mana 1,9 juta adalah individu dewasa dan 150.000 individu dengan usia kurang dari 15 tahun (WHO, 2016). Di Indonesia khususnya, berdasarkan data dari Pusat Data dan Informasi Departemen Kesehatan R.I (2006) sejak ditemukannya kasus AIDS pertama kali pada tahun 1987 hingga 31 Desember 2006, ditemukan total 13.424 kasus yang terjangkit HIV di antaranya ada sekitar 5230 orang dengan HIV positif (belum menunjukkan gejala AIDS) dan 8.194 dengan kasus AIDS. Sementara itu, kasus komulatif AIDS kembali mengalami peningkatan pada 2015 yakni sejumlah 77.112 kasus (Kementeriam Kesehatan Republik Indonesia, 2013). Sejak diakui keberadaannya oleh World Health Organization (WHO) pada tahun 1981, hingga kini, AIDS disebut telah merenggut lebih dari 25 juta jiwa (https:// kitasetara.org, 2017). Fakta itu membuat AIDS menjadi salah satu epidemik global yang paling menghancurkan. AIDS menjadi masalah multinasional yang amat serius.

Penyakit HIV/AIDS dapat menyebabkan banyak perubahan secara fisik, mulai dari tahap awal HIV hingga AIDS. Pada tahap awal, pasien akan mengalami demam, panas dingin, sakit otot, sakit tenggorokan, sariawan, hingga pada tahap akhir infeksi yakni menderita AIDS. Pada saat menderita AIDS perubahan fisik yang terjadi adalah perubahan bentuk tubuh seperti penurunan berat badan yang cepat, kelelahan yang ekstrim dan tidak jelas, pembengkakan yang berkepanjangan dari getah bening kelenjar di ketiak, selangkangan, atau leher, diare yang berlangsung selama lebih dari seminggu, luka pada mulut, anus, atau alat kelamin, pneumonia, merah, coklat, merah muda, atau keunguan bercak pada atau di bawah kulit atau di dalam mulut, hidung, atau kelopak mata, dan lain sebagainya (https://www.aids.gov, 2015).

Banyaknya perubahan yang terjadi kemudian mengarahkan pasien pada perasaan tidak berguna dan negatif dikarenakan pasien tidak mampu lagi melakukan hal-hal yang dulu dapat dilakukan. Sudah sejak lama diperkirakan 
bahwa gangguan emosional seperti depresi berat, kehilangan harapan, ketidakberdayaan, takut, perasaan bersalah, marah, ketidakpercayaan dan rasa putus asa serta gangguan psikologis lainnya yang pada umumnya akan terjadi pada pasien HIV/AIDS di mana secara jelas akan mengganggu kesejahteraan hidup individu yang berpengaruh pada fungsi emosi, sosial, dan fisik (Hawari, 2004; Remien \& Rabkin, 2001; Sarafino, 2006).

Kompleksitas masalah yang dihadapi pasien HIV/AIDS menunjukkan bahwa afek yang tidak menyenangkan menjadi dominan. Adanya permasalahan yang kompleks pada pasien, selain menghadapi rasa sakit dari penyakitnya sendiri, munculnya stigma, prevalensi, dan diskriminasi dari keluarga, teman, maupun tenaga kesehatan ini pun, jelas akan sangat mempengaruhi psikologis pasien HIV/AIDS. Ketika keadaan kesehatan psikologi pasien menurun, tentunya akan menurunkan keadaan fisik pasien. Telah diketahui bahwa kesehatan mental sangat mempengaruhi fisik, termasuk di dalamnya fungsi biologis pasien khususnya sistem imun pasien HIV/AIDS yang di mana seharusnya sistem imun atau salah satunya CD4 (limfosit) pasien harus mampu dipertahankan dalam jumlah minimal tertentu. Argumen ini didukung hasil penelitian Howell, Kern, dan Lyubomirsky (2007) yang mengungkapkan bahwa kesejahteraan subjektif juga berkaitan erat dengan fungsi kekebalan tubuh di mana dapat meningkatkan respon imun yang berarti kesejahteraan dapat mempengaruhi beberapa proses biologis. Selanjutnya Costanzo, dkk (Diener \& Chan, 2011) menyebutkan bahwa individu yang sedang marah memiliki respon imun yang lemah terhadap vaksin sedangkan individu dengan optimistik yang tinggi akan memiliki respon imun yang kuat. Tidak hanya itu, Moskowitz (2003) mengungkapkan bahwa afek positif dapat menjadi active ingredient dalam hubungannya dengan angka kematian
HIV+. Diener dan Chan (2011) menambahkan bahwa afek positif berasosiasi dengan menurunnya tingkat kematian pasien dengan HIV. Jadi, kesejahteraan subjektif pasien HIV/AIDS dapat mempengaruhi kondisi biologis pasien.

Berdasar penjelasan-penjelasan sebelumnya, dibutuhkan suatu usaha untuk mengatasi permasalahan terkait psikis maupun fisik pasien HIV/AIDS. Pavot dan Diener (Linley \& Joseph, 2004), bahwa ada beberapa faktor yang memengaruhi kesejahteraan subjektif, di antaranya adalah temperamen, perubahan hidup, hubungan sosial, pendapatan, pengangguran, dan pengaruh sosial budaya. Berdasarkan beberapa faktor tersebut, peneliti tertarik untuk membahas mengenai hubungan sosial yang menjadi faktor yang memengaruhi kesejahteraan subjektif, khususnya pada pasien HIV/AIDS. Argumen ini diperkuat dengan adanya stigma yang menjadi penyebab terjadinya perubahan psikologis pada HIV/AIDS sehingga banyak orang yang kemudian menghindari pasien HIV/AIDS atau sama sekali tidak memberi dukungan untuk mampu bertahan (Mahajan, dkk, 2010; Remien \& Rabklin, 2001)

Mengacu pada penjelasan sebelumnya, artinya ada keterkaitan antara kedua hal ini, bahwasanya hubungan sosial yang baik akan menghasilkan hal yang positif dalam diri individu sehingga dapat membuat kesejahteraan subjektif menjadi lebih baik. Menurut Vetlesen (Linley \& Joseph, 2004), hubungan sosial lebih fokus pada metode berbagi, memberi, dan peduli terhadap sesama. Hal tersebut didukung Turnercobb, dkk (2002), yang melakukan penelitian terhadap 137 orang dengan HIV/AIDS positif, bahwa individu akan mengalami penyesuaian positif, yang mana merupakan afek positif dan juga kepuasan jika dapat menjalin rasa aman dengan orang lain. 
Bentuk dukungan dimaksud dapat
berupa dukungan pribadi maupun kelompok. Pada kondisi ini, peneliti tertarik untuk melihat pengaruh dukungan kelompok pada kesejahteraan subjektif pada pasien HIV/AIDS. Bentuk dukungan ini dapat dilakukan dengan berbagai macam metode, salah satunya adalah terapi kelompok pendukung. Terapi kelompok pendukung efektif untuk pasien yang mengalami penurunan di beberapa aspek kehidupan sering dikaitkan dengan penyakit medis (Brabender, Fallon, \& Smolar, 2004). Hal ini senada dengan yang disampaikan Tselebis dkk., (2016) bahwasanya konteks dan proses dalam psikoterapi kelompok secara eksplisit hadir dalam prinsip dinamika sistem, dapat menawarkan suatu penyembuhan yang sesuai dengan apa diharapkan karena termasuk di dalamnya pengalaman penyembuhan dari suatu distres emosional melalui ekspresi emosi, merasakan kebersamaan, penerimaan, dan berkembangnya social skill melalui proses modelling.

Terapi kelompok pendukung adalah media bagi sekumpulan individu dengan masalah yang sama untuk berbagi pendapat dan kebutuhan satu sama lain. Anggota kelompok dapat saling mendukung dan berbagi pengalaman yang tidak menyenangkan pada peserta lain. Akan ada kelompok pendukung untuk menjadi wadah penyembuhan psikologis karena orangorang dengan masalah yang sama akan saling berbagi kisah. Kesamaaan pengalaman dan perasaan menginisiasikan keolompok menjadi lingkungan yang dapat mengerti kebutuhan psikologis pasien HIV/AIDS. Terapi kelompok pendukung dalam beberapa penelitian terhadap kanker, bully, dan AIDS telah menunjukkan hasil yang positif (Bateganya, Amanyeiwe, Roxo \& Dong, 2015; Robinson \& Maines, 2008; Thompson, dkk, 2013). Hasil positif ini muncul dikarenakan rasa dukungan yang ada dalam kelompok itu sendiri, karena ketika dalam kelompok yang memiliki masalah (rendahnya harga diri dan rasa siasia hidup), dukunganlah yang paling dibutuhkan untuk dapat meningkatkan afekafek positif dalam diri individu (Brabender, dkk, 2004). Melihat fenomena seperti ini, menjadikan penelitian tentang terapi kelompok pendukung akan menarik jika dilakukan pada pasien HIV/AIDS.

Berdasarkan pemaparan di atas, tujuan dari penelitian ini adalah untuk mengetahui pengaruh terapi pendukung kelompok terhadap kesejahteraan subjektif pada pasien HIV/AIDS. Peneliti juga mengajukan hipotesis penelitian yaitu (a) adanya perbedaan skor kesejahteraan subjektif pada kelompok eksperimen antara sebelum dan setelah diberikan intervensi berupa terapi kelompok pendukung, (b) terdapat peningkatan skor kesejahteraan subjektif pada kelompok eksperimen setelah diberikan intervensi dibandingkan dengan kelompok yang tidak diberi intervensi (kelompok kontrol). 
Gambar 1. Kerangka Teoritis Pengaruh Terapi Kelompok Pendukung terhadap Kesejahteraan Subjektif Pasien HIV/AIDS

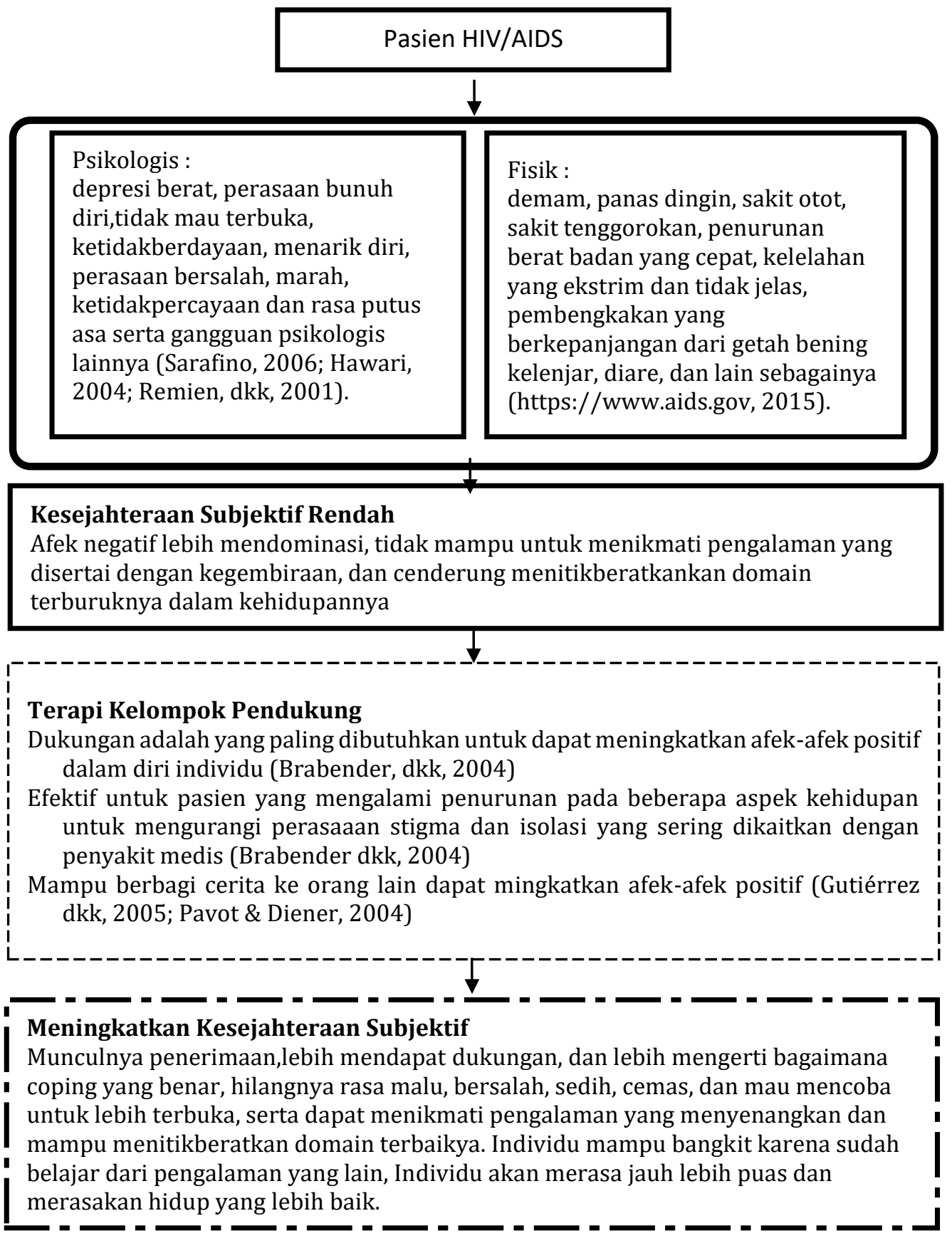




\section{METODE PENELITIAN}

\section{Rancangan Penelitian}

\begin{abstract}
Penelitian ini merupakan quasi eksperimen dengan prates-pascates kelompok kontrol dan eksperimen. Kelompok eksperimen adalah kelompok yang menerima intervensi berupa terapi kelompok pendukung, sedangkan kelompok kontrol sebagai kelompok waiting list yang akan tetap diberi intervensi terapi kelompok pendukung sesuai dengan yang akan diberikan kepada kelompok eksperimen. Penelitian eksperimen dilakukan untuk meneliti kemungkinan adanya hubungan sebab akibat di antara variabel-variabel dengan cara menghadapkan kelompok eksperimen pada beberapa macam kondisi perlakuan dan membandingkan akibat atau hasilnya dengan kelompok kontrol yang tidak dikenai perlakuan.
\end{abstract}

\section{Subjek Penelitian}

Subjek penelitian ini adalah pasien dengan HIV/AIDS, dengan rentang usia antara 21-40 tahun, berjenis kelamin lakilaki dan perempuan, sebagai penderita HIV/AIDS dengan masa penderitaan kurang dari satu bulan hingga 2 tahun. Subjek dalam penelitian ini berjumlah 6 orang yang terbagi menjadi 2 kelompok eksperimen dan kontrol masing-maing tiga orang. Subjek penelitian telah melewati masa screening dengan hasil bagi subjek yang memiliki skor SWLS sangat rendah, rendah, sedang, dan/atau memiliki skor afek negatif yang lebih besar dibandingkan skor afek positif.

\section{Metode Pengumpulan Data}

Penelitian ini menggunakan di antaranya alat ukur, observasi, dan wawancara. Alat ukur yang digunakan sebanyak dua buah skala untuk mengukur kesejahteraan subjektif, di antaranya adalah
Satisfaction With Life Scale (SWLS) untuk mengukur aspek kognitif dan Positive And Negative Affect Scale (PANAS) untuk mengukur aspek afeksi. Skala kepuasan hidup (SWLS) memiliki koefisien reliabilitas Cronbach's $\alpha=0,859$ ( $\mathrm{N}=5$ aitem) dengan validitas bergerak dari $0,541-0,732$ ( $p>0,3$ ). Sementara itu, skala afeksi (PANAS) terdiri dari skala afek positif (PA) dan skala afek negative (NA). Skala afek positif (PA) memiliki koefisien reliabilitas Cronbach's $\alpha=$ $0,851 \quad(\mathrm{~N}=10$ aitem $)$ dengan validitas bergerak dari $-0,221$ - 0,816 yang pada akhirnya menghasilkan 9 butir aitem valid. Skala afek negative (NA) memiliki koefisien reliabilitas Cronbach's $\alpha=0,886 \quad(\mathrm{~N}=10$ aitem) dengan validitas bergerak dari 0,346 - 0,789. Pengukuran prates dilakukan sebelum dilaksanakannya terapi, pascates dilakukan setelah dilaksanakannya terapi, dan tindak lanjut dilakukan 10 hari pasca terapi.

\section{Prosedur Intervensi}

Terapi yang digunakan adalah terapi kelompok pendukung. Modul merujuk berdasarkan modifikasi modul yang telah dibuat Kurniawan (2015) dengan mengacu pada faktor-faktor terapi kelompok pendukung, yakni Supportive Factors, Self Revelation, Learnings from Others, dan Psychological Work Factors. Terapi ini dilakukan dalam beberapa kali pertemuan, yakni 4 kali dengan setiap sesinya kurang lebih 100 menit.

\section{Teknik Analisis Data}

Metode analisis data yang digunakan dalam penelitian ini adalah analisis deskriptif, yakni analisis deskriptif kuantitatif dan analisis deskriptif kualitatif. Analisis deskriptif kuantitatif digunakan untuk melihat perubahan skor kesejahteraan subjektif untuk setiap pengukuran setelah diberikan intervensi berupa terapi 
kelompok pendukung melalui gained score. Pengujian berdasarkan gained score yaitu menggunakan selisih prates dan pascates serta prates dan tindak lanjut. Analisis data kualitatif dilakukan dengan wawancara secara individual dengan tujuan untuk mendapatkan pernyataan langsung dari subjek berupa perubahan yang diperoleh setelah mengikuti terapi, selain itu juga dengan mengolah data hasil observasi yang telah dilakukan. Wawancara dilakukan pada saat sebelum intervensi, sesuai setiap sesi intervensi, dan juga pada saat tindak lanjut.

\section{HASIL PENELITIAN}

Deskripsi data;

Tabel 1. Tabel informasi skor Skala Kepuasan Hidup (SWLS)

\begin{tabular}{|c|c|c|c|c|c|c|c|}
\hline & Nama & JK & $\begin{array}{l}\text { Pra } \\
\text { Tes }\end{array}$ & $\begin{array}{l}\text { Pasca } \\
\text { tes }\end{array}$ & $\begin{array}{l}\text { Follow } \\
\text { up }\end{array}$ & $\begin{array}{l}\text { Gained } \\
\text { Score } \\
\text { (Prates- } \\
\text { Pascates) }\end{array}$ & $\begin{array}{l}\text { Gained } \\
\text { Score } \\
\text { (Prates- } \\
\text { Follow up) }\end{array}$ \\
\hline \multirow{3}{*}{ 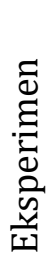 } & $\mathrm{AA}$ & $\mathrm{L}$ & 22 & 25 & 26 & 3 & 4 \\
\hline & EDM & $\mathrm{P}$ & 15 & 19 & 22 & 4 & 7 \\
\hline & INE & $\mathrm{L}$ & 14 & 22 & 25 & 8 & 11 \\
\hline \multirow{3}{*}{ 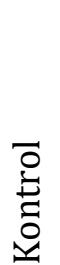 } & WEN & $\mathrm{P}$ & 12 & 12 & 12 & 0 & 0 \\
\hline & SUK & $\mathrm{L}$ & 17 & 19 & 12 & 2 & -5 \\
\hline & PR & $\mathrm{L}$ & 21 & 22 & 23 & 1 & 2 \\
\hline
\end{tabular}

Tabel 2. Deskripsi Data Penelitian Skala Kepuasan Hidup (SWLS)

\begin{tabular}{llll}
\hline \multirow{2}{*}{ Kelompok } & Klasifikasi & \\
\cline { 2 - 4 } & & Prates-Pascates & Prates-Follow up \\
\hline Eksperimen & Minimum & 3 & 4 \\
& Maksimum & 8 & 11 \\
& Mean & 5 & 7,33 \\
& SD & 2,646 & 3,512 \\
\hline Kontrol & Minimum & 0 & -5 \\
& Maksimum & 2 & 2 \\
& Mean & 1 & -1 \\
& SD & 1 & 3,606 \\
\hline
\end{tabular}

Tabel 2. diatas menunjukkan perbedaan skor antara prates-pascates hingga prates-tindak lanjut pada kelompok eksperimen yakni meningkat sebesar 2,33 dari mean 5,00 hingga 7,33. Selanjutnya, terlihat bahwa kelompok kontrol juga mengalami perbedaan skor mean, tapi bukan peningkatan, melainkan penurunan skor. Skor turun sebanyak 2 angka, yakni mean kelompok kontrol dari 1,00 hingga 1,00. Jadi, dapat disimpulkan bahwa perbedaan skor menunjukkan bahwa ada 
perubahan yang terjadi, meningkat berarti ada perubahan positif dan sebaliknya.

Tabel 3. Informasi skor Skala Afeksi (PANAS)

\begin{tabular}{|c|c|c|c|c|c|c|c|}
\hline & Nama & JK & $\begin{array}{l}\text { Pra } \\
\text { tes }\end{array}$ & $\begin{array}{l}\text { Pasca } \\
\text { tes }\end{array}$ & $\begin{array}{l}\text { Follow } \\
\text { up }\end{array}$ & $\begin{array}{l}\text { Gained Score } \\
\text { (Prates- } \\
\text { Pascates) }\end{array}$ & $\begin{array}{l}\text { Gained } \\
\text { Score } \\
\text { (Prates- } \\
\text { Follow up) }\end{array}$ \\
\hline \multirow{3}{*}{ 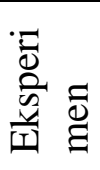 } & AA & $\mathrm{L}$ & 11 & 15 & 21 & 4 & 10 \\
\hline & EDM & $\mathrm{P}$ & -1 & 3 & 9 & 4 & 10 \\
\hline & INE & $\mathrm{L}$ & 1 & 1 & 6 & 0 & 5 \\
\hline \multirow{3}{*}{$\begin{array}{l}\overrightarrow{0} \\
\stackrel{0}{0} \\
0 \\
1\end{array}$} & WEN & $\mathrm{P}$ & 12 & 12 & 12 & 0 & 0 \\
\hline & SUK & $\mathrm{L}$ & 17 & 19 & 12 & 2 & -5 \\
\hline & PR & $\mathrm{L}$ & 21 & 22 & 23 & 1 & 2 \\
\hline
\end{tabular}

Tabel 4. Deskripsi Data Penelitian Skala Afeksi (PANAS)

\begin{tabular}{lllllll}
\hline Nama & JK & $\begin{array}{l}\text { Pra } \\
\text { tes }\end{array}$ & $\begin{array}{l}\text { Pasca } \\
\text { tes }\end{array}$ & $\begin{array}{l}\text { Follow } \\
\text { up }\end{array}$ & $\begin{array}{l}\text { Gained Score } \\
\text { (Prates- } \\
\text { Pascates) }\end{array}$ & $\begin{array}{l}\text { Gained Score } \\
\text { (Prates- } \\
\text { Follow up) }\end{array}$ \\
\hline AA & L & 11 & 15 & 21 & 4 & 10 \\
EDM & P & -1 & 3 & 9 & 4 & 10 \\
INE & L & 1 & 1 & 6 & 0 & 5 \\
\hline
\end{tabular}

Tabel 4. di atas menunjukkan bahwa seluruh subjek kelompok eksperimen mengalami peningkatan skor pada aspek afeksi kesejahteraan subjektif. Peningkatan skor dari prates hingga pascates rata-rata meningkat 4 angka dan pada prates hingga tindak lanjut, terdapat 2 subjek meningkat 10 angka dan 1 subjek meningkat 5 angka pada aspek afeksi kesejahteraan subjektif.

\section{Hasil Analisis Data Kuantitatif}

Skor kesejahteraan subjektif subjek dapat diketahui dengan mengolah data mentah menjadi skor baku. Skor baku yang lazim digunakan dalam bidang penilaian adalah $z$-score dan $t$-score. Pada perhitungan kali ini yang digunakan adalah t-score. Tujuannya untuk menghilangkan tanda minus pada hasil perhitungan z-score sehingga lebih mudah untuk dipahami. Rumus $t$-score yang digunakan dalam perhitungan kali ini adalah sebagai berikut: $T$-score $=50+10 \mathrm{Z}$. Sedangkan rumus untuk mencari skor total kesejahteraan subjektif: SWB $=$ SWLS + ( PA - NA $)$.

Skor untuk mengetahui tingkat kesejahteraan subjektif didapatkan dengan cara menjumlahkan skor SWLS dengan hasil dari pengurangan untuk Positive Affect dan Negative Affect (Libran, 2006). Perhitungan untuk mencari kesejahteraan subjektif dilakukan menggunakan bantuan SPSS dan dengan tujuan untuk melihat perbedaan tingkat kesejahteraan subjektif ketika pengukuran prates, pascates, dan follow up pada kelompok eksperimen dan kelompok kontrol. 
Tabel 5. Rerata Skor Kesejahteraan Subjektif

\begin{tabular}{llccc}
\hline & Kelompok & N & Mean Rank & Sum of Ranks \\
\hline TSWB_Pra & Eksperimen & 3 & 3.67 & 11.00 \\
& Kontrol & 3 & 3.33 & 10.00 \\
& Total & 6 & & \\
\hline TSWB_Pasca & Eksperimen & 3 & 3.67 & 11.00 \\
& Kontrol & 3 & 3.33 & 10.00 \\
& Total & 6 & & \\
\hline TSWB_Foll & Eksperimen & 3 & 4.33 & 13.00 \\
& Kontrol & 3 & 2.67 & 8.00 \\
& Total & 6 & & \\
\hline
\end{tabular}

Analisis kuantitatif menggunakan gained score untuk variabel kesejahteraan subjektif dikelola melalui analisis Mann Whitney. Pada kelompok eksperimen diperoleh rerata prates sebesar 3,67, rerata pascates sebesar 3,67, dan rerata tindak lanjut sebesar 4,33. Artinya, terjadi peningkatan skor dari pascates-tindak lanjut dan juga dari prates-tindaklanjut sebesar 0,66 . Selain itu, diperoleh informasi bahwa skor eksperimen lebih tinggi pada saat pascates dan tindak lanjut dibandingkan kelompok yang tidak diberi perlakuan (kelompok kontrol).

Dengan demikian dapat disimpulkan bahwa hipotesis penelitian diterima atau terdapat perbedaan tingkat kesejahteraan subjektif antara sebelum dan sesudah dilakukan terapi kelompok pendukung. Selain itu juga efek terapi kelompok pendukung mampu bertahan hingga saat terapi selesai (tindak lanjut), serta terdapat perbedaan tingkat kesejahteraan subjektif antara kelompok yang diberi perlakuan dengan kelompok yang tidak diberi perlakuan.

\section{Hasil Analisis Data Kualitatif}

Analisis kualitatif dilakukan pada kelompok eksperimen berdasarkan hasil observasi dan wawancara yang dilakukan dari sebelum, saat, dan setelah diberikan intervensi. Tujuan dari analisis kualitatif ini adalah untuk mengetahui pengalaman dan perilaku subjek selama mengikuti terapi kelompok pendukung. Subjek pertama mengatakan banyak mendapat hal-hal baru selama berlangsungnya terapi, belajar untuk mengubah pikiran-pikiran negatif menjadi positif. "Ya aku harus menerima penyakit ini, walau pada awalnya aku tu berpikir untuk menghayal aku harus kena HIV aja tu ga pernah, aku takut banget mbak". "Mereka ternyata punya banyak masalah juga ya, dan mereka berhasil bertahan. Awalnya aku pikir aku akan kurus, dirawat dirumah sakit, terus mati. Tapi ya ternyata ga gitu ya. Aku belajar banyak dari sini". Ketika subjek pertama berusaha menerapkan pelajaran yang diperoleh dari kelompok pendukung, subjek mengatakan hal tersebut sangat bermanfaat di mana mampu membuat subjek merasakan perasaan yang lebih tenang dan mampu mensyukuri hidupnya. Subjek mengatakan "Jadi kalau misalnya ada 
masalah, kita belajar dari pengalaman yang ada, kayak pengalamannya mbak $E^{* *}$ yang bilang kalau stress minum obat, dan sebagainya, nah kalau aku diam-diam dikamar, ya aku belajar gimana caranya supaya aku ga makin lemah, jadi aku mikir yang baik-baik. Ya emang ga instant si mbak, beberapa minggu ini aku terapin ya emang awalnya agak susah, susah sih, tapi ya aku coba jadinya lebih lepas ringan, makanya aku tertarik buat nyoba terus" Subjek menyatakan dengan adanya sharing dalam kelompok antar sesama HIV, maka akan sangat menolong kondisi subjek, khususnya kondisi psikis.

Subjek kedua menjelaskan bahwa terapi ini membantu subjek dalam mengelola pikiran dan emosi yang dirasakan. Subjek kedua mengatakan "Nah bedanya, kalau dulu aku tu kayak dikit-dikit cemas, gelisah, takut gitu walaupun suamiku udah terima aku yang positif B20, ya aku kayaknya ga yakin aja terus abis itu masih kebayang-bayang rasa bersalahku ke anakku. Nah sekarang aku lebih toleransi sih, terus lebih perhatian. Soalnyakan yang bisa ngerawat anakku cuman aku sama suamiku, terus juga suamiku makin perhatian gitu, aku jadi agak lega. Masa laluku biar jadi masa lalu dan masa sekarang harus bener gitu, mbak". Ada beberapa permasalahan subjek yang mampu untuk dipecahkan dalam diskusi kelompok yang sudah dilakukan. Subjek kedua menambahkan "oh ya mbak, aku tu dulu tiap hari minum obat, tiap ada masalah mesti sakit kepala, dan sejak pertemuan kedua itu, aku udah ga minum obat. Ya aku coba untuk tenang, tarik napas dan lain-lain. Ternyata itu berhasil. Waw" Diskusi ini membuat subjek mampu belajar untuk mengurangi perasaan-perasaan negatif yang ada dan membuat subjek belajar untuk tidak mengulangi kesalahan- kesalahan di masa lalu. Subjek mengaku bahwa kini subjek mampu menghilangkan sakit kepala dengan mengelola pikiran dan emosinya akhirnya berhasil menghilangkan rasa sakit kepala tanpa obat.

Subjek terakhir mengatakan bahwa subjek mendapat banyak wawasan dalam terapi yang diikuti. Subjek mulai untuk mencoba mengubah perilaku subjek untuk tujuan yang lebih berarti kedepannya, yakni hidup sehat dan tidak mamu menularkan kepada yang lain. Subjek menyatakan bahwa setelah terapi selesai, subjek mampu menolak untuk berhubungan seksual tanpa pengaman, walaupun tawaran yang diberikan lebih menggiurkan. Pada saat tindak lanjut, subjek menjelaskan ingin sekali berhenti dari pekerjaan saat ini, di mana subjek mulai menyadari bahwa pekerjaan ini tidak sehat, tapi subjek masih mencari solusi pekerjaan ketika suatu saat berhenti bekerja seperti saat ini. "Аpa ya, emang apa ya bedanya. Emm... oh kalau masalah kerja ya, kita sempat bahas kerjaan kan ya. Apa ya kalau aku tu mbak, jadi mikir sekarang, kalau bisa ninggalin pekerjaan ini aku mau banget. Aku udah ga mau kerja begini lagi, ga sehat. Tapi ya gimana dek aku juga ga tau mau kerja apa, kalau ada kerjaan lain aku mau banget.". "emm kalau itu laki aku ya, ini keluarga aku dek. Aku ingin pulang, aku pengen ketemu mereka. Padahal dulu taulah ya yang kayak aku pernah bilang, aku ga mau pulang-pulang lagi. Udah berapa tahun aku disini dan begitu. Tapi kemarin tu, kayaknya kalau sama keluarga lebih enak ya. Ya gitulahh" Subjek juga mulai memiliki keinginan untuk pulang kampung di mana sebelumnya subjek sangat tidak mau memikirkan hal tersebut. Hal ini dikarenakan mulai munculnya keinginan untuk menghargai apa yang dimiliki saat ini dan bertemu dengan keluarga. 
Berdasarkan data hasil penelitian di atas, dapat disimpulkan bahwa hipotesis dalam penelitian ini diterima. Pertama, terdapat perbedaan skor kesejahteraan subjektif sebelum dan setelah diberikan intervensi pada kelompok eksperimen. Kedua, terdapat peningkatan skor sebelum dan setelah diberikan intervensi pada kelompok eksperimen. Ketiga, terdapat perbedaan skor kesejahteraan subjektif kelompok eksperimen dan kelompok kontrol, di mana kelompok eksperimen mengalami peningkatan skor pada seluruh aspek kesejahteraan subjektif dan kelompok kontrol mengalami penurunan pada aspek kesejahteraan subjektif.

\section{PEMBAHASAN}

Tujuan dari penelitian ini adalah untuk mengetahui pengaruh terapi kelompok pendukung terhadap kesejahteraan subjektif pada pasien HIV/AIDS. Hasil menunjukkan bahwa terapi kelompok pendukung berpengaruh terhadap kesejahteraan subjektif pasien HIV/AIDS. Hal ini dibuktikan oleh adanya perbedaan skor kesejahteraan subjektif pada kelompok eksperimen antara sebelum dan setelah diberikan intervensi, yakni terdapat peningkatan skor setelah diberikan intervensi. Selain itu juga terdapat perbedaan skor antara kelompok eksperimen dan kelompok kontrol dilihat dari rerata skor yang menunjukkan adanya peningkatan skor untuk kedua aspek pada kelompok eksperimen dan adanya penurunan skor rerata pada kelompok kontrol. Jadi, dapat disimpulkan ada pengaruh terapi kelompok pendukung terhadap kesejahteraan subjektif pada pasien HIV/AIDS.

Hasil penelitian ini didukung beberapa penelitian sebelumnya. Penelitian- penelitian sebelumnya di antaranya adalah penelitian dari Paudel dan Baral (2015) bahwa kelompok pendukung adalah intervensi terbaik untuk mengatasi stigma dan diskriminasi. Stigma dan diskriminasi merupakan stressor lingkungan yang dirasakan oleh individu yang kemudian dapat menurunkan kesejahteraan subjektif akibat menurunnya kepuasan hidup dan meningkatnya afek negatif. Selain itu, Bateganya, dkk (2015) menyatakan bahwa dengan menerapkan kelompok pendukung sebagai intervensi, maka akan terkait dengan penurunan angka kematian dan morbiditas, peningkatan retensi dalam perawatan dan peningkatan kualitas hidup, termasuk di dalamnya tentang kesejahteraan. Hal tersebut didukung oleh penelitian Siedlecki, Salthouse, Oishi, dan Jeswani (2014) yang dilakukan terhadap 1.111 individu antara usia 18 dan 95 menunjukkan hasil adanya hubungan antara dukungan sosial dengan aspek dari kesejahteraan subjektif (yaitu, kepuasan hidup, afek positif, dan afek negatif). Sweetland, Lazzarus, Freeman, dan Saloner (2004) juga mendukung penelitian ini di mana dalam bukunya dinyatakan bahwa kelompok pendukung disebut sebagai "tempat penyembuhan" karena memungkinkan individu memenuhi kebutuhan dan menyembuhkan diri individu sendiri, juga membantu orang lain untuk melakukan hal yang sama, di lingkungan yang saling memahami dan peduli, khususnya pada pasien HIV/AIDS. Berdasarkan penelitian sebelumnya, penelitian ini kemudian menegaskan bahwa ada pengaruh terapi kelompok pendukung terhadap kesejahteraan subjektif pasien HIV/AIDS. Pengaruh ini menunjukkan bahwa terapi kelompok pendukung mampu meningkatkan kesejahteraan subjektif individu. 
Terapi kelompok pendukung sendiri memiliki 4 faktor terapeutik yang memiliki potensi untuk memberikan keuntungan psikologis bagi anggotanya, di antaranya adalah supportive factor, self revelation, learning from others, dan psychological work factors (Kurniawan, 2015). Faktor-faktor terapeutik ini kemudian dapat mempengaruhi kesejahteraan subjektif individu dalam kelompok. Supportive factor menjelaskan bagaimana subjek mampu menerima dan memiliki rasa kebersamaan untuk melihat dan menghadapi masalah. Selain itu self revelation menjelaskan bahwa ketika anggota kelompok saling percaya dengan anggota lainnya dan mau membuka dirinya. Pada saat berjalannya proses terapi, ada salah seorang anggota berbagi tentang pikiran buruknya mengenai kekhawatiran masa depan karena diri subjek mengidap penyakit menular seksual (PMS). Sementara itu anggota lain berusaha untuk menjelaskan berbagai macam permasalahan yang sudah pernah terjadi sebelumnya yang lebih parah, sehingga subjek mampu menerima keadaannya saat ini juga anggota lain yang membantu mencari solusi sehingga subjek mampu untuk mengelola perasaan negatif akan masa depan, seperti cemas. Makino dan Tagami (1998) sejak lama sudah menjelaskan bahwa ada hubungan antara penerimaan khususnya pada keterbukaan diri dengan kesejahteraan subjektif. Keterbukaan ini kemudian akan meningkatkan afek-afek positif, seperti harga diri dan efikasi diri (Nöstlingera, Bakeera-Kitaka, Buyze, Loos dan Buvé, 2015). Nöstlingera, dkk (2015) menegaskan bahwa perlunya intervensi psikologi untuk mendampingi keterbukaan seseorang. Jadi dapat disimpulkan bahwa penerimaan dan kebersamaan dalam anggota kelompok mampu membuat subjek menerima keadaannya dan mengelola perasaannya, sehingga dapat meningkatkan kepuasan hidup dan afek positif.

Pada setiap sesi dalam penelitian ini, terdapat banyak ilmu untuk diperoleh dan dibagi kepada anggota kelompok. Bercerita dan mendengarkan pengalaman akan memunculkan proses pembelajaran. Menurut Usman (2008) diskusi kelompok merupakan proses yang berguna untuk menghadapi interaksi dengan berbagai informasi atau pengalaman, kesimpulan atau solusi untuk memecahkan sebuah masalah. Adanya solusi merupakan hasil dari proses pembelajaran anggota tentag cara menghadapi masalah dan juga akan memunculkan psychological work factors yang akan muncul karena keterlibatan antar sesama anggota kelompok untuk memahami diri sendiri.

Terapi ini mengandung edukasi dan dukungan yang kuat antar sesama anggota kelompok. Pada analisis kualitatif, subjek menyatakan bahwa hal-hal yang dapat memberikan semangat hidup yang kuat, salah satunya adanya belajar dari support group di mana subjek lebih mudah mendapatkan contoh yang nyata sehingga subjek mampu untuk memahami diri akibat perbandingan kondisi yang dilakukan subjek. Subjek juga mampu untuk terbuka akan kondisi dan situasinya sehingga subjek dapat memperoleh solusi. McCrae dan Costa (Gutiérrez, Jiménez, Hernández \& Puente, 2005) menyebutkan bahwa keterbukaan dapat membawa seseorang memperoleh afek positif sejalan dengan afek negatifnya.

Secara kualitatif, penelitian ini menunjukkan bahwa kelompok pendukung merupakan hal yang sangat bermanfaat untuk membuat pasien HIV menjadi lebih hidup, karena faktor-faktor terapeutik yang 
ada dalam terapi kelompok pendukung. Tidak dapat dipungkiri bahwa setiap subjek mengalami peningkatan kesejahteraan subjektif yang berbeda-beda. Perbedaan ini diakibatkan oleh faktor-faktor yang mempengaruhinya, seperti dukungan yang diperoleh berbeda-beda, dan pemaknaan dalam proses terapi, serta masalah-masalah subjektif subjek. Subjek menjadi mampu mengelola emosi dan pikiran sehingga menjauhi obat ketika sakit kepala dan juga subjek lain mampu untuk menyusun tujuan hidup yang lebih berarti bagi diri subjek tersebut tanpa menyesali masa lalunya.

Tulisan ini punya sejumlah keterbatasan dalam penelitian ini adalah kurangnya pendampingan terhadap pengisian kuesioner pada sesi screening yang dilakukan peneliti. Selanjutnya adalah mengenai pertanyaan yang ada di kuesioner, beberapa masih menggunakan bahasa baku, padahal subjek screening di antaranya fasih berbahasa jawa, dan tidak begitu fasih dalam bahasa Indonesia, sehingga butuh penjelasan lebih dari peneliti. Selanjutnya, keterbatasan dalam pemilihan sampling yang bisa saja mengandung bias, maksudnya belum tentu mewakili seluruh anggota populasi yang ada, di mana cenderung hanya dapat diaplikasikan pada komunitas yang dituju.

\section{SIMPULAN DAN SARAN}

\section{Simpulan}

Berdasarkan hasil penelitian dapat disimpulkan bahwa adanya pengaruh terapi kelompok pendukung terhadap kesejah teraan subjektif pada pasien HIV/AIDS. Hal ini berdasarkan analiasis data kuantitif dan kualitatif. Berdasarkan hasil follow up, dapat dilihat bahwa subjek mampu memper tahankan efek dari terapi kelompok pendukung selama 10 hari setelah post test. Hal ini berarti bahwa terapi kelompok pendukung berhasil meningkatkan kesejahteraan subjektif subjek dan subjek dapat mempertahankan hal tersebut setelah pelatihan tidak dilakukan lagi.

Berdasarkan hasil wawancara singkat yang dilakukan semua subjek, mereka mengaku bahwa terapi kelompok pendukung membuat subjek merasa memiliki kelompok yang bisa diajak untuk berbagi dan juga memperoleh kekuatan baru dari proses terapi. Semua subjek juga mampu untuk mengubah pikiran negatif menjadi postif, sehingga subjek mampu mengurangi rasa sakit fisik yang dirasakan. Subjek juga mengatakan bahwa mereka menjadi lebih bersyukur dengan apa yang dimiliki pada saat ini karena setelah diskusi dengan kelompok pendukung, subjek merasa lebih beruntung, merasa memiliki teman dan penguatan baru, dan merasa tidak sendiri. Efeknya adalah subjek menjadi pribadi yang lebih baik dan afek negatif mulai berkurang. 


\section{Saran}

Untuk peneliti selanjutnya, dapat mengadakan anggota terapi yang lebih banyak sehingga lebih banyak informasi yang dapat diperoleh antar sesama anggota kelompok, jika intervensi yang diberikan merupakan terapi kelompok, khususnya terapi kelompok pendukung. Selanjutnya, untuk peneliti yang mengambil subjek dengan penyakit kronis, agar dapat menyesuaikan jumlah pertanyaan dalam skala, kemudian menyesuaikan skala dengan kebutuhan responden dengan bahasa yang mudah dimengerti dan tulisan yang besar. Peneliti selanjutnya juga sangat disarankan untuk mendampingi setiap pengisian skala untuk setiap subjek penelitian.
Pasien HIV/AIDS sangat disarankan untuk memiliki kelompok berbagi, karena itu sangat bermanfaat dalam meningkatkan kesejahteraan subjektif pasien agar pasien dapat menjalani hidup dengan gembira dan lebih semangat. Pasien juga disarankan untuk mencoba terbuka, karena dukungan ketika pasien sakit sangat dibutuhkan untuk mendapatkan kesejahteraan subjektif yang baik. Meningkatnya kesejahteraan subjektif dapat dimulai dengan lebih menghargai halhal yang ada sekitar, menurunkan rasa sesal terhadap pengalaman masa lalu dengan cara menerima apa yang terjadi sekarang dan merancang tujuan di masa depan. Selanjutnya, mengelola pikiran-pikiran dan emosi yang dirasakan agar mampu untuk meningkatkan afek-afek postif dalam hidup. 


\section{DAFTAR PUSTAKA}

AIDS.GOV. (2015). Symptoms of hiv. Artikel Online. Diakses pada tanggal 16 Maret 2017 dari https://www.aids.gov/hivaids-basics/hiv-aids-101/signs-andsymptoms/

Aprilia, R. (2015) .Hubungan antara subjective well-being dengan self management pada ibu bekerja di rumah sakit X. Jurnal Fakultas Psikologi Universitas Bina Darma Palembangi. Diunduh dari http://digilib.binadarma.ac.id/files/d isk1/135/123-123-riniaprill-6706-1jurnalr-i.pdf pada 8 Maret 2016

Bateganya M., Amanyeiwe, U., Roxo U., \& Dong, M. (2015). The impact of support groups for people living with hiv on clinical outcomes: A systematic review of the literature. NHS Public Access, 68, 368-374

Brabender, V.A., Fallon, A.E., \& Smolar, A.I. (2004) . Essential of group therapy. Canada : John Wiley \& Sons, Inc.

Diener, E., Scollon, C.N., \& Lucas, R.E. (2003). The evolving concept of subjective well-being: The multifaceted nature of happiness. Advances In Cell Aging and Gerontology, 15, 187-220

Diener, E. \& Chan M. Y. (2011). Happy people live longer : Subjective well-being contributes to health and longevity. Applied Psychology : Health and WellBeing, 3 (1), 1-43

Gutiérrez, J.L.G., Jiménez, B.M., Hernández, E.G., \& Puente, C.P. (2005). Personality and subjective well-being: Big five correlates and demographic variables. Personality and Individual Differences, 38, 1561-1569
Hawari, D. (2004). Al Qur'an : Ilmu kedokteran jiwa dan kesehatan jiwa". Edisi III (Revisi). Yogyakarta: PT. Dana Bhakti Prima Yasa.

Howell, R.T., Kern, M.L., \& Lyubomirsky, S. (2007). Health benefits: Metaanalytically determining the impact of well-being on objective health outcomes. Health Psychology Review, 1, 83-136

Kementerian Kesehatan Republik Indonesia.(2013). Estimasi dan proyeksi hiv/aids di indonesia tahun 2011-2016. Jakarta : Kementerian Kesehatan RI

Kitasetara.org. (2017). Mau dibawa ke mana penanggulangan aids di indonesia di masa mendatang?. Artikel Online. Diakses dari https://kumparan.com/kitasetara/mau-dibawa-ke-manapenanggulangan-aids-di-indonesia-dimasa-mendatang pada tanggal 17 Maret 2017

Kurniawan, Y. (2015). Terapi kelompok pendukung (support group therapy) pada orangtua pasien talasemia. Modul Terapi Kelompok Pendukung. Yogyakarta: Program Magister Psikologi Profesi UII.

Libran, E, C. (2006). Personality dimensions and subjective well-being. The Spanish Journal of Psychology, 9(1), 38-44.

Linley, P.A \& Joseph S. (2004) . Positive psychology in practice. New Jersey: John Wiley \& Sons. Inc

Mahajan, A.P., Sayles, J.N., Patel, V.A., Remien, R.H., Ortiz, D., Szekeres, G.,.. Coates., T.J. (2010). Stigma in the hiv/aids epidemic: A review of the literature and recommendations for the way forward. NIH Public Access : AIDS, 22(2), 67-69 
Makino, Y. \& Tagami, F. (1998). Subjective well-being and self-acceptance. Shinrigaku Kenkyu, 69 (2),143

Moskowitz, JT. (2003). Positive affect predicts lower risk of aids mortality. Paychosom Med, 65 (4), 620

Nöstlingera, C., Bakeera-Kitaka, S., Buyze, J., Loos, J. \& Buvé, A. (2015). Factors influencing social self-disclosure among adolescents living with hiv in eastern africa. AIDS Care, 27 (S1), 3646

Paudel, V. \& Baral, K. (2015). Women living with HIV/AIDS (WLHA), battling stigma, discrimination, and denial and the role of support groups as a coping strategi: A riview of literature. Reproductive Health, 12 (53), 1-9

Pusat Data dan Informasi Departemen Kesehatan R.I. (2006). Situasi hiv/aids di indonesia tahun 2987-2006. Jakarta : Pusat data dan Informasi Departemen Kesehatan RI

Remien, R.H. \& Rabkin, J.G. (2001). Psychological aspect of living with hiv disease. West J Med, 175, 332-335

Robinson, G. \& Maines, B. (2008) . Bullying : A complete guide to the support group method. India : Replika Pvt Ltd.

Sarafino, E.P. (2006). Health Psychology: Biopsychosocial interaction. Fifth Edition. New York: John Wiley \& Sons Inc.

Siedlecki, KL., Salthouse, T.A., Oishi, S. \& Jeswani, S. (2014) .The relationship between social support and subjective wellbeing across age. NIH : Soc Indic Res, 117(2), 561-576
Simon, G.E. (2001). Treating depression in patients with chronic disease. West J Med, 175 (5), 292-293

Sweetland, A., Lazzarus, R., Freeman, M., \& Saloner, K. (2004) . Mental health and hiv/aids :psychosocial support groups in antiretroviral (arv) therapy programmes. Johannesburg : WHO Press.

Thompson, Tess, Rodebaugh, Thomas, L., Pérez,... Donna B. (2013) . Perceived social support change in patients with early-stage breast cancer and controls. NIH Public Assess : Health Psychology, 32(8), 886-895

Tselebis, A., Pachi, A., Ilias, I., Kosmas, E., Bratis, D.,... Tzanakis, N. (2016) . Strategies to improve anxiety and depression in patients with copd : A mental health perspective. Review Neuropsychiatric Disease and Treatment, 12, 297-328

Turner-cobb, J.M., Gore-felton, C., Marouf, F., Koopman, C., Kim, P.,... Spiegel, D. (2002). Coping, social support, and attachment style as psychosocial correlates of adjustment in men and women with hiv/aids. Journal of Behavioral Medicine, 25(4), 337-353

Usman, M. U. (2008). Menjadi guru profesional. Bandung : PT. Remaja Rosdakarya

WHO. (2016). Global summary of the hiv/aids epidemic, December 2015. Diakses dari http://www.who.int/hiv/data/en/ pada 16 Maret 2017 